Pamiętnik Literacki 2017, 4, s. 87-103
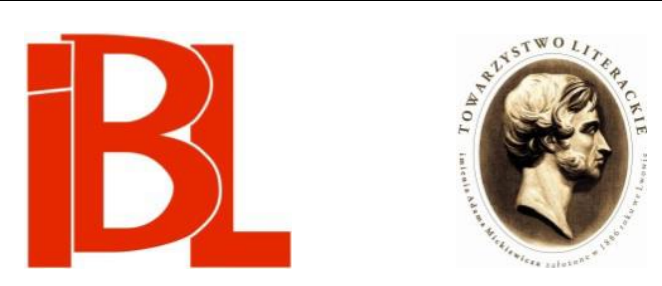

\title{
Być jak Leonardo Sciascia. Gustaw Herling-Grudziński i sycylijskie obsesje
}

Magdalena Śniedziewska 
Pamiętnik Literacki CVIII, 2017, z. 4, PL ISSN 0031-0514

DOI: $10.18318 / \mathrm{pl} .2017 .4 .6$

MAGDALENA ŚNIEDZIEWSKA Instytut Badań Literackich PAN, Warszawa

\section{BYĆ JAK LEONARDO SCIASCIA GUSTAW HERLING-GRUDZIŃSKI I SYCYLIJSKIE OBSESJE*}

W Dzienniku pisanym noca Gustaw Herling-Grudziński wspomina, że jako jeden z pierwszych komentatorów bardzo entuzjastycznie wypowiadał się o wydanym w 1956 roku zbiorze esejów Leonarda Sciascii Le parrocchie di Regalpetra (Parafie w Regalpetrze). Herling, nie kryjąc dumy, otwiera pochodzącą z 9 IV 1975 notatkę stwierdzeniem:

Leonardo Sciascia le Sicilien, jak go w tytule entuzjastycznej „rozkładówki” nazywa „Le Monde”, jest moim faworytem od wielu lat: pisałem o jego Parafiach $w$ Regalpetra i Śmierci Inkwizytora na długo przed dzisiejszymi chórami rzymskich czy paryskich zachwytów. [D 134] ${ }^{1}$

Dalsza część wywodu Grudzińskiego jest syntetyczną próbą charakterystyki twórczości Sycylijczyka. Herling stara się przybliżyć nie tylko genologiczne i stylistyczne problemy jego powieści, ale także poruszaną w nich tematykę oraz przyjmowaną przez Sciascię polityczną, czy szerzej - ideologiczną, postawę:

Jest [Sciascia] w średnim wieku (czyli moim), stroni od wszelkich koterii literackich, w poglądach po jakobińsku lewy, ale na dystans od komunistów, wypracował sobie własną formę krótkiej powieści, $z$ domu eseistycznej, ostatnio wzbogaconej o elementy romansu kryminalnego. Ma styl suchy, precyzyjny, jakby używał cyrkla i piórka kreślarskiego, brzydzący się ornamentacją i w budowie fraz porównywalny chyba $z$ budową minerałów. Jest wybornym znawcą mafii sycylijskiej, ale nie w sposób powierzchowny i sensacyjno-kronikarski: drąży głębiej, odsłania podskórny proces mafijnej „sycylianizacji” współczesnych Włoch. I mitoburcą: rozbija, między innymi, mit o religijności Sycylijczyków. [D 134]

W podobnym tonie o Sciascii jako o autorze diagnozującym mafijną „sycylianizację" kontynentalnych Włoch wypowiada się w La luce e il lutto (Światło i żałoba) (w szkicu zatytułowanym Pro Sicilia) Gesualdo Bufalino, inny bardzo sycylijski autor kreujący w swojej twórczości mit rodzinnej wyspy: „Sciascia napisał w któ-

* Badania zostały sfinansowane ze środków Narodowego Centrum Nauki przyznanych w ramach finansowania stażu po uzyskaniu stopnia naukowego doktora na podstawie decyzji numer DEC$-2015 / 16 / \mathrm{S} / \mathrm{HS} 2 / 00133$.

1 Skrótem D odsyłam do: G. Herling-Grudzińs ki, Dziennik pisany noca 1973-1979. Posł. Z. Ku dels ki. Warszawa 1995. Pisma zebrane. T. 4. Red. Z. Ku d els ki. Ponadto stosuje jeszcze jeden skrót do utworu tego autora: $Z$ = Zielona Kopuła. Sycylijska opowieść epistolarna. W: Biała noc miłości. Opowiadania. Warszawa 2002. Jw., t. 12. Liczby po skrótach oznaczają stronice. 
rymś miejscu, że [...] Sycylia, w pewien sposób, dokonuje sycylianizacji reszty Włoch"2.

Herlinga wyraźnie cieszy fakt, iż Sciascia, jego ulubiony włoski pisarz, jest mu bliski nie tylko za sprawą literackiej techniki, ale i poglądów politycznych oraz zainteresowań. Zdaje się, że Grudziński celowo eksponuje te cechy osobowości sycylijskiego twórcy, które mogłyby mu posłużyć jako autocharakterystyka. Podobnie należałoby postrzegać wpis z 14 II 1990. Całą notatkę poświęcił autor problemowi „czarnowidztwa”, którego mistrzem był - zdaniem Herlinga - Émile Cioran. Dziełom Ciorana przeciwstawia Grudziński twórczość Sciascii (i swoją):

„Czarnowidztwo” Ciorana powstaje z nadmiaru nienawiści. Istnieje inne „czarnowidztwo”: jego źródłem jest nadmiar miłości. Był mu do śmierci wierny pisarz sycylijski Leonardo Sciascia, autor książeczki Nero su nero. Sporo „czarnego na czarnym” także w moim Dzienniku pisanym noca, z podobnego (mam nadzieję) źródła ${ }^{3}$.

To nie jedyne ślady - wzrastającego wraz z upływem lat - zainteresowania Sycylijczykiem. W roku 1964 spod ręki Herlinga wyszło dość obszerne omówienie wydanej wówczas książki Morte dell'Inquisitore (Śmierć Inkwizytora) autorstwa Sciascii. Ta, oparta na faktach, ledwie 100-stronicowa książeczka, różniąca się od jego „mafijnych” powieści, jest - zdaniem Grudzińskiego - najważniejszym dziełem w dorobku Sciascii. Sąd ten potwierdza dużo późniejszy wpis, z 10 V 1997. Herling komentuje tam wydaną w 1996 roku biografię Sycylijczyka Il maestro di Regalpetra. Vita di Leonardo Sciascia (Mistrz z Regalpetry. Życie Leonarda Sciascii), której autorem jest Matteo Collura ${ }^{4}$ :

Pękata biografia mojego ulubionego pisarza Leonarda Sciascii [...] jest dziełem sycylijskiego dziennikarza. Autor, Matteo Collura, zrobił, co mógł, a mógł niestety mało, uformowany całkowicie w szkole pospiesznej żurnalistyki. Po prostu ulepił figure pisarza $z$ drobnych gazetowych „michałków” i „kawałków". Ale i za to trzeba mu być wdzięcznym. Książka jest bogatym źródłem informacji.

Jedna $z$ tych informacji bardzo mnie uradowała. Zawsze twierdziłem $z$ uporem, narażając się albo na wyraz pogardliwego zdumienia na twarzach rozmówców, albo w najlepszym razie na wzruszenie ramion, że nauczyciel z Regalpetra (był nim w pierwszej fazie swojego życia) wzniósł się najwyżej w swej obfitej twórczości szczupłym tomikiem Śmierć Inkwizytora ${ }^{5}$.

W moim szkicu postaram się odpowiedzieć m.in. na pytanie, co sprawiło, że Herling tak wysoko ocenił Morte dell'Inquisitore, i co o jego własnym pisarstwie mówi ten wybór. Konieczne okaże się prześledzenie nawet najdrobniejszych uwag Grudzińskiego o dziełach Sciascii oraz dokładne przyjrzenie się utworom polskiego autora, w których dostrzec możemy wpływ Sciascii i w których dodatkowo pojawiają się wątki sycylijskie. Jednym z nich jest - „prześladująca” i kusząca Herlinga - mafia. W notatce z 5 IV 1996 czytamy:

2 G. Bufalino, La luce e il lutto. W: Opere. T. 1. A cura di M. Corti, F. Ca put o. Introduzione M. Corti. Milano 2010, s. 1138.

3 G. Herling-Grudziń s ki, Dziennik pisany noca 1989-1992. Warszawa 1997, s. 98-99. Pisma zebrane, t. 7.

4 M. Collu r a, Il maestro di Regalpetra. Vita di Leonardo Sciascia. Milano 2007.

5 G. Herling-Grudziński, Dziennik pisany noca 1997-1999. Warszawa 2000, s. 62. Pisma zebrane, t. 11. 
Mieszkam we Włoszech przeszło czterdzieści lat, a więc od dawna śledzę mentalność i działania mafii sycylijskiej. Nie mogę się naturalnie równać z nieodżałowanym Leonardo Sciascia, jednym z czołowych przedstawicieli dzisiejszej literatury włoskiej, ale sporo już wiem na temat mafii ${ }^{6}$.

Nie budzi wątpliwości fakt, że Herling nie zna mafii tak, jak rodzimy Sycylijczyk Sciascia, pozostaje jednak pytanie, czy dorównuje mu pisarsko. W swoich utworach Sciascia, a za nim Herling, nierzadko porusza podobną problematykę. Należy do niej, oczywiście, wątek mafijny ${ }^{7}$ (o czym niebawem) oraz kwestie związane $z$ sycylijskim malarstwem dawnym, a dokładniej: $z$ dziełami, których autorem jest Antonello da Messina. Herling, pisząc o realizacjach Ecce Homo Antonella, przywołuje Sciascię w roli autorytetu:

Antonello da Messina namalował trzy Ecce Homo. We wszystkich Chrystus płacze, chociaż tylko w jednym widać łzy na policzku, a w dwóch pozostałych Antonello poprzestał na wzbierającym szlochu, który lada chwila wybuchnie. Przerażony i umęczony wzrok, usta wykrzywione w grymasie skargi. Leonardo Sciascia, świetny pisarz i rodak sycylijskiego mistrza, twierdzi, że w tych trzech obrazach do głosu doszedł „obiektywizm” obserwatora. Antonello studiował ludzi rażonych nieszczęściem. I zdołał utrwalić wyraz tępego bólu, maskę fizycznego cierpienia, bez światła boskości, bez aury właściwej męce Odkupiciela, po prostu $z$ naciskiem na okropność tortury, na okrucieństwo oprawców i szyderstwo gapiów. [D 286]

Herling, zainspirowany spostrzeżeniami Sciascii ${ }^{8}$, ukazuje - istniejąca już w XV wieku - sycylijska skłonność do odzierania cierpienia Boskiego z wymiaru metafizycznego. Do tego wątku powróci później (także w kontekście rozważań Sciascii), podejmujac temat procesji odgrywanych na sycylijskich ulicach i placach, a przedstawiających Mękę Pańską. W innej dziennikowej notatce, z 10 V 1993, Herling - jakże śmiało - połączy zobrazowaną przez Antonella sycylijską obojętność z problemem mafii. Oczywiście, przewodnikiem pisarza znów staje się Sciascia:

W opinii historyków sztuki święty Sebastian z arcydzieła Antonella da Messina (ozdoby galerii drezdeńskiej) stoi przebity strzałami na placu zmyślonym, który jest po prostu owocem wyobraźni czy kreacji syntetycznej mistrza sycylijskiego przeszczepionego do Wenecji. Zgadza się z tym Leonardo Sciascia, sugerując jednak, że w syntetycznym wizerunku najwięcej cech zaczerpnął Antonello z rodzin-

6 G. Herling-Grudziński, Dziennik pisany noca 1993-1996. Warszawa 1998, s. 566. Jw., t. 10 .

7 Zob. G. Herling-Gru dzińs ki, W. B ol e cki, Rozmowa XVI: „Schronisko Lunatyczne” (1998). W: Rozmowy w Neapolu. Rozmowy przeprowadził, oprac., przygot. do druku W. B ol e cki. Warszawa 2000, s. 279: „Mafia jest zjawiskiem bardzo skomplikowanym historycznie, socjologicznie, politycznie, a także kulturowo. Sam najbardziej cenię rozważania na temat mafii, których autorem jest Leonardo Sciascia. I mimo że pisał on na temat mafii rzeczy naprawdę odważne, nie unikając tematów dla mafii najbardziej drażliwych, to jednak nikt nigdy nie zrobił mu żadnej krzywdy. A przecież nie było to trudne, bo mieszkał na sycylijskiej prowincji. Mam na ten temat prywatną teorię, że Sciascia za swoją mądrość był w skrytości podziwiany i szanowany przez mafiosów, którzy wiedzieli, że jego pisarskie rozważania są całkowicie bezinteresowne, że są one wynikiem jego ciekawości”.

8 Zob. L. S cia s cia, L'ordine delle somiglianze. W: L'opera completa di Antonello da Messina. Presentazione L. Sciascia. Apparati critici e filologici G. Mandel. Milano 1967, s. 7: „Można poczynić podobne obserwacje na temat obrazów Ecce Homo, Salvator Mundi i Ukrzyżowań: oblicza tępego bólu, maski cielesnego cierpienia; bez Boskiego światła, bez świadomości czynienia ofiary, dzięki której odkupiona zostanie cała ludzkość. To ludzie cierpiący tortury, znoszący szyderstwa, umierający w agonii, przybici do krzyża, ofiary ludzkiego okrucieństwa i przeznaczenia”. 
nej Messyny. Cała atmosfera obrazu zdaje się świadczyć, że mamy do czynienia z placem sycylijskim w upalne popołudnie, gdy od morza wieje scirocco, gdy ostre światło słońca zamazują kędzierzawe chmurki na niebie, gdy w powietrzu wisi leniwa obojętność.

Obojętność jest w obrazie wrażeniem kluczowym. Antonello, w imię narzucenia aury obojętności widzowi, zharmonizował pierwszy plan z tłem. On, który w swoich Ecce Homo podkreślał grymas bólu i nawet łzy w twarzy Chrystusa, tutaj namalował Sebastiana nieczułego na rany, łagodnego, z oczami wzniesionymi lekko do góry; jak gdyby święty nie czuł zupełnie strzał w nagim ciele. Tło jest w pełni dostosowane do Sebastiana na pierwszym planie: kobiece rozmówki na balkonach, matka z niemowlęciem w cieniu portyków, śpiący obok schodów mężczyzna, trzy pary na głównej osi - rycerzy lub strażników, kupców i dam. Wszyscy obojętni, łącznie z centralną (i największą) na placu postacią męczennika. Osoby z tła zdają się jej w ogóle nie dostrzegać.

Jestem przekonany, że „sycylijskość” placu Antonella rozpoznał Sciascia w obojętnych, którzy nic na pozór nie widzą i nic, również na pozór, nie wiedzą i nie czują ${ }^{9}$. I w tym sensie arcydzieło z galerii drezdeńskiej można potraktować jako metaforę Włoch, która dziś rozpada się, pod codziennymi ciosami, w proch i pył. Obojętni Włosi obudzili się naraz, wszystko chcą widzieć i wiedzieć, mają dosyć kraju, w którym wszystko odbywało się po kryjomu (głównie złodziejstwo i korupcja), a na „sycylijskim placu” oglądano co pewien czas trupa w kałuży krwi, dzieło mafii powiązanej tysiącami nici z polityką i nie tylko polityką. (To ja - niech mi wolno będzie się pochwalić - w opowiadaniu Oko Opatrzności ubiegłem wyobraźnią fakty: związki mafii z masonerią i diecezją w Trapani opisałem na długo przed wykryciem ich przez organa śledcze) ${ }^{10}$.

Sycylijska pozorowana obojętność, doprowadzona do skrajności w braku reakcji na zniewolenie, będące konsekwencją podziemnych mafijnych rządów, nie jest wyłącznie XX-wiecznym fenomenem. Jej korzenie - przekonują i Herling, i Sciascia - tkwią dużo głębiej. Obojętność cierpiącego świętego Sebastiana, wzmocniona obojętnością znajdujących się na placu ludzi, jest pełną beznadziei reakcją obronną spalonej słońcem, leniwej Sycylii. Wszechogarniający marazm okazuje się doskonała glebą, na której uformowała się hierarchiczna organizacja mafijna. Dotknięcie istoty tego zjawiska staje się pisarskim celem Grudzińskiego. W rozmowie z Włodzimierzem Boleckim nie kryje on dumy, że jako pierwszy w Oku Opatrzności przedstawił sekretne układy sycylijskiej mafii:

Sformułowałem w tym opowiadaniu tezę, którą z dzisiejszej perspektywy można nazwać profetyczną. Wspominam mianowicie o połączeniu mafii i masonerii, a rzecz rozgrywa się na Sycylii [... ${ }^{11}$.

9 Zob. ibidem: „Plac jest sceną przedstawiającą okrutną obojętność wobec męki świętego Sebastiana. I nie mówimy, że ten plac z drezdeńskiego Świętego Sebastiana przywodzi na myśl sycylijską architekturę; przeciwnie, raczej utrzymujemy, że został on wymyślony przez Antonella z elementów o różnej proweniencji, w poszukiwaniu odpowiedniości między architekturą a postaciami, która okazuje się jedną z najdoskonalszych, jakie kiedykolwiek osiagnięto w malarstwie. Ale za sprawą kobiety, która przedstawiona została przy arkadach $z$ dzieckiem $w$ ramionach, postaci spoglądających $\mathrm{z}$ tarasów, donic i krat okiennych, manierki zwisającej $\mathrm{z}$ jednego $\mathrm{z}$ wysokich okien, stworzona została atmosfera domu, messyńskiego popołudnia. Można by rzec, że wieje scirocco: to scirocco, przez które Anglik Brydon w Messynie czuł się tak, jakby jego nerwy były przeszywane prawie tak samo, jak ciało świętego Sebastiana przez strzały. I mężczyzna, którego sen zmorzył na gołym bruku, wytworna scenka, którą para wystawia pod altaną, zatrzymane chmury, światło, wszystko to zdaje się świadczyć o popołudniu przesyconym nudą i scirocco".

10 Her ling-Grudzińs ki, Dziennik pisany noca 1993-1996, s. 53-54.

11 G. Herling - Gru dzińs ki, W. B ol e c ki, Rozmowa XXII: „Oko Opatrzności”, „Z biografii Diego Baldassara. Introdukcja”, „Zeszyt Williama Mouldinga, emeryta. Objaśnienie nabywcy zeszytu”. W: Rozmowy $w$ Dragonei. Rozmowy przeprowadził, oprac., przygot. do druku W. B ol e c ki. Warszawa 1997, s. 277. 
Okazało się, że intuicja literacka nie zawiodła Herlinga, jak tłumaczy dalej Boleckiemu:

w moim opowiadaniu do masonerii dołącza się mafia sycylijska, co, gdy to napisałem, mogło wydawać się bardzo dziwne. Tymczasem w sześć miesięcy potem, w tej samej miejscowości, którą opisuję, w Trapani, w której nigdy nie byłem, wykryto współpracę mafii i masonerii! I zrobił się z tego ogromny skandal ${ }^{12}$.

W powstałym w 1988 roku opowiadaniu Oko Opatrzności wątek mafijny, umiejętnie wpleciony w główną narrację, przywodzi na myśl pisarstwo Sciascii, pełne celowych i znaczących niedopowiedzeń. Sądzę, że jedno ze źródeł inspiracji mogła stanowić opublikowana w 1974 roku powieść Sciascii zatytułowana Todo modo. Nie mamy wątpliwości, że Herling znał Todo modo - świadczy o tym notatka w dzienniku z 9 IV 1975:

Jego [tj. Sciascii] nową powieść Todo modo zrodziła niewątpliwie histeria „historycznego kompromisu", paktu zaproponowanego katolikom przez komunistów, głoszonego urbi et orbi przez wszystkie bębny partyjne i jakąś (trudną do oszacowania) część dzwonów kościelnych. [D 134]

Grudziński w kilku zaledwie zdaniach celnie przybliża nam najistotniejsze wątki Todo modo:

Rzecz dzieje się w pustelni-hotelu, gdzie co roku odbywają się tygodniowe rekolekcje dla wybranych demochrześcijańskich notablów: ministrów, prezesów przedsiębiorstw i banków, senatorów i deputowanych. Kierownikiem rekolekcji jest diaboliczny i piekielnie (właściwe słowo) inteligentny ksiądz [...]. [D 134-135]

Imprezę zakłóca seria zabójstw, jednak:

Sciascia nie posuwa się do ich wyjaśnienia, sugeruje tylko, że rekolekcyjne ustronie sprzyja przypuszczalnie załatwianiu wewnętrznych mafijnych porachunków między chadeckimi notablami. [D 135]

Rekonstruując akcję powieści, natrafiamy na liczne niedomówienia, za których sprawą Sciascia oddaje specyfikę mafijnej rzeczywistości. Podobnie czyni Herling w Oku Opatrzności. Zarówno u Sciascii, jak i u Grudzińskiego szokujące hipotezy na temat powiązań mafijnych pojawiają się na zasadzie przypuszczeń, sugestii rozsianych w tekście, prawda bowiem nie może ujrzeć światła dziennego. Czytelnik co najwyżej domyśla się rozwiązania, ale ostatecznie pozostaje $\mathrm{z}$ pustymi rękami. Zgodnie $\mathrm{z}$ regułami zmowy milczenia (omertà) wiemy i widzimy tylko tyle, ile mafia pozwala nam ujrzeć. Resztę - co podkreśla w swoim opowiadaniu Herling - podszeptuje wyobraźnia.

W Oku Opatrzności narrator (pisarz), składający po śmierci swojego przyjaciela Malcolma zeznania w neapolitańskiej kwesturze, komentuje właściwe mu literackie skrzywienie:

No, ale rozpędziłem się i zabrnałem w dywagacje literackie, które ma pan prawo uciąć bez litości. Jakkolwiek, będąc z powołania i zawodu pisarzem, nie potrafię myśleć o ulubionych przez pana „samych faktach” poza ich głębszym, tajemniczym przeważnie, kontekstem. Każdy z nas ma swoją deformację profesjonalna, ja tak samo jak pan ${ }^{13}$.

13 G. Herling-Gru dziń s ki, Oko Opatrzności. W: Dziennik pisany noca 1984-1988. Warszawa 1996, s. 410. Pisma zebrane, t. 6. 
To właśnie wyobraźnia pisarska pozwoliła na postawienie śmiałej hipotezy dotyczącej związków mafijnego światka z masonerią i duchowieństwem. Fakty, od których Herling wychodzi, stają się solidną podstawą do snucia przypuszczeń, zapętlania narracji, prowadzenia quasi-filozoficznych rozważań. Grudziński zbliża się w ten sposób do metody wykorzystanej przez Sciascię w takich utworach, jak Morte dell'Inquisitore, Zniknięcie Majorany (La scomparsa di Majorana) czy Il teatro della memoria (Teatr pamięci). Można odnieść wrażenie, że polski pisarz dlatego szczególnie wysoko ocenia dokumentalne teksty Sciascii, by podnieść rangę własnych, w których wykorzystuje analogiczną technikę artystyczną. $Z$ tego względu nie bez znaczenia okazuje się fakt, że w późniejszym utworze, zatytułowanym Zielona Kopuła. Sycylijska opowieść epistolarna, Herling „projektuje” szkic Leonardo Sciascia jako historyk, podkreślając w taki sposób wagę dzieł Sycylijczyka opartych na faktach ${ }^{14}$. Podobnego zdania jest Andrzej Zieliński, który stwierdza:

Nie rozminiemy się chyba z prawdą, zakładając, że czytana po raz pierwszy w 1964 r. Śmierć Inkwizytora podsyciła zainteresowanie Herlinga starymi kronikami włoskimi i siedemnastowiecznymi dziejami południa Włoch. I że idąc niejako tropem Sciascii, będzie on odtąd coraz częściej sięgał do odległych w czasie, ale wstrząsających podstawami współczesnej świadomości moralnej epizodów. U obu pisarzy trudno podważyć szacunek dla dokumentu. Co najwyżej w prozie Sciascii więcej jest elementów kreacji i wyobraźni, więcej refleksji „społecznej”, szczególnie wówczas, gdy z autora rekonstruującego dawne historie przemienia się we wrażliwego interpretatora swojej Sycylii, a przede wszystkim - w wybornego znawcę mafii ${ }^{15}$.

Innym ważnym elementem charakterystycznym dla pisarstwa Herlinga, pozwalającym na zestawienie jego pisarstwa $z$ dziełami Sciascii, jest pogłębiona refleksja nad istotą sycylijskości (sicilianità). W Oku Opatrzności Grudziński, ukazując miejsce spotkania loży masońskiej, stworzył iście sycylijską scenerię:

Na koniec lipca zwołano posiedzenie Magna Grecia na Sycylii. Miało się odbyć w Erice, tym ślicznym miasteczku średniowiecznym w pobliżu Trapani. Posiedzenie było nadzwyczajne, planowano zdaje się unię loży neapolitańskiej z sycylijska. [...] Miejscem posiedzenia było podziemie opuszczonego klasztoru franciszkańskiego trzy kilometry za Erice, honory domu pełnił sędziwy i wyjątkowo inteligentny ksiądz. Masońskie zgromadzenie w świętym, choć skonsekrowanym przybytku, $\mathrm{z}$ duchownym $\mathrm{w}$ roli gospodarza? Właśnie tak. I tym razem w niezwykłej scenerii. Długi stół dla uczestników, w jednym z kątów lochu ułożone w piramidę czaszki zmarłych dawno zakonników, na pułapie plamy przylepionych, śpiących nietoperzy. W grupie sycylijskiej szczególnym mirem cieszył się tęgi, rosły mężczyzna o ponurej twarzy. Nazywano go Don Calogero. Od pierwszej chwili Malcolm zwęszył w nim mafijną grubą rybę. Związki między masonerią i mafią, pod przychylnym i dobrotliwym okiem sługi Bożego, kapłana Kościoła? Tego było za dużo nawet dla Malcolma ${ }^{16}$.

W obrazie czaszek, towarzyszacych obradom, ujawnia się słynna sycylijska obsesja śmierci, która powróci w bardziej rozbudowanej formie w Zielonej Kopule.

Autorką wspomnianego szkicu (którego nie poznajemy) jest Dora, $\mathrm{z}$ wykształcenia historyk, jedna z bohaterek sycylijskiej opowieści: „Dora pomagała mojej matce w gospodarstwie domowym i w lepszych chwilach sporo czytała. Napisała nawet szkic Leonardo Sciascia jako historyk, który ukazał się w mediolańskich "Quaderni storici". Pamiętam o Twojej [tj. Gustava] admiracji dla Śmierci Inkwizytora, więc przy okazji rzuć na ten szkic okiem” (Z 132).

15 A. Zi elińs ki, Gustaw Herling-Grudziński i wspótczesna literatura włoska. „Przegląd Humanistyczny" 1995, nr 2, s. 34.

16 Herling-Grudzińs ki, Oko Opatrzności, s. 411. 
O ile w Oku Opatrzności wątek sycylijski nie jest zanadto rozwinięty, o tyle w Zielonej Kopule próba zgłębienia problemu sycylijskości stanowi sedno rozważań prowadzonych $\mathrm{w}$ formie epistolarnego dialogu ${ }^{17}$. Autorami listów są mieszkający w Neapolu: Gustavo - zafascynowany Sycylią i pragnący ją dogłębnie poznać pisarz, alter ego Grudzińskiego, oraz pracujący naukowo historyk Rosario ${ }^{18}$, Sycylijczyk, zajmujący się badaniem arabskiego dziedzictwa („struny arabskiej”) swojej wyspy.

Omawiając jeden z etapów sycylijskiej podróży ${ }^{19}$, Gustavo, zwróciwszy się do Rosaria, podejmuje problem wielokulturowości, a lepiej rzec - „wielostrunowości”, wyspy:

Segesta, samotna świątynia grecka na zboczu doliny, tak piękna, że słowa bledną na jej widok, zainicjowała w mojej podróży sycylijskiej strunę grecką. Wiedziałem już, że Sycylia jak wspaniały instrument składa się $z$ wielu strun. Ty poświęciłeś się badaniom struny arabskiej, inni opisali bizantyjską czy hiszpańska, mój ulubiony pisarz Sciascia ukuł nazwę la corda pazza, struna szalona, sycylijskie skłonności obłąkańcze. Miałem nadzieję skoncentrować się kiedyś na sycylijskiej corda del potere, na strunie władzy. To jej drgnienia wypada nazwać ponurą muzyką mafii? [Z 117]

Rosario, z właściwą historykowi wnikliwością, rozwija podjęty przez Gustava wątek. Po raz kolejny w związku z rozważaniami dotyczącymi charakteru Sycylijczyków przywołany zostaje - w roli autorytetu - Sciascia:

Caro Gustavo, bardzo mnie zainteresował Twój wywód o „strunach”, o ich znaczeniu w formowaniu się charakteru Sycylijczyków. Zajmuję się „struną arabską”, ale kto wie, czy nie masz racji: może większą rolę odegrała grecka. Wyczuwał to także, choć niejasno, Sciascia. Raz napomknął mianowicie o „radykalnej niereligijności” Sycylijczyków, a w szkicu o świętach religijnych na Sycylii w jednym tylko zdaniu odkrył rzecz niezmiernie ważną: „Mieszkańcy naszej Wyspy są całkowicie nieprzemakalni na wszystko, co jest tajemnicą wiary, niewidzialnym objawieniem, metafizyką"20.

Czyżby to były cechy właśnie Greków? [Z 118]

Nie mamy wątpliwości, że rozważania Sciascii odcisnęły się mocno na twórczości Herlinga. Pisarz daje temu wyraz wkładając w usta Rosaria słowa autora eseju Feste religiose in Sicilia (Święta religijne na Sycylii) z 1965 roku. Przede wszystkim jednak sądy głoszone przez Gustava możemy postrzegać jako poglądy Herlinga. Jestem przekonana, że pisarz w pełni utożsamia się z wykreowanym w Zielonej Kopule bohaterem. Świadczą o tym fragmenty rozmowy z Boleckim, dotyczącej

Podobnego zdania jest W. B o le c k i - w rozmowie z Herlingiem stwierdza on: „W Oku Opatrzności, które jest opowiadaniem neapolitańskim, pojawiają się motywy sycylijskie, natomiast Zielona Kopuła jest sycylijska w całości” (G. Herling-Grudziń s ki, W. B ole c ki, Rozmowa XV: „Zielona Kopuła. Sycylijska opowieść epistolarna” 〈1998〉. W: Rozmowy w Neapolu, s. 267). Pierwowzorem postaci Rosaria był sycylijski przyjaciel Grudzińskiego, historyk Rosario Romeo. Zob. ibidem, s. 271.

19 Herling, co prawda, odbył kilka podróży na Sycylię, jednak długa, miesięczna wyprawa $z$ roku 1972, o której wspomina w opowiadaniu, jest - jak dowodzi F. Tomaszewski (Sycylijski wędrowiec. W: Drogi i „stacje wygnania”. Podróże i powroty Gustawa Herlinga-Grudzińskiego. Gdańsk 2006, s. 242) - zmyślona.

20 Zob. L. S c i a s c i a, Feste religiose in Sicilia. W: La corda pazza. Scrittori e cose della Sicilia. Milano 2007, s. 217: „Ten, absolutnie bezbożny, sposób pojmowania i wyznawania religii, która jest trwale, rygorystycznie i szczegółowo skodyfikowana w każdym przejawie wewnętrznego i zewnętrznego kultu, ma swoje korzenie w głębokim materializmie, w całkowitej odporności na wszystko, co jest tajemnica, niewidzialnym objawieniem, metafizyką. 
sycylijskiego opowiadania. Grudziński, przybliżając źródła powstania Zielonej Kopuły, wyznaje, że jednym $z$ decydujących impulsów „była ambicja stworzenia w tym opowiadaniu obrazu Sycylii, która mnie fascynuje od chwili mojego osiedlenia się we Włoszech, a której nadal jeszcze nie znam tak, jak bym chciał”.

Jest to dla mnie wyspa niezwykła, tajemnicza, słynna $\mathrm{z}$ wielu zjawisk nie spotykanych w tak zwanych Włoszech kontynentalnych. I która nawet w swojej literaturze pokazuje odrębność cywilizacyjną, historyczna i psychologiczna. Dlatego piszę o „strunach” cywilizacji sycylijskiej. Mój przyjaciel zajmował się „struną arabską”, to znaczy badał wpływ cywilizacji arabskiej na kulturę sycylijską. Ja próbowałem zwrócić mu uwagę na „strunę grecką, która, moim zdaniem, odgrywa na Sycylii rolę największą kształtuje poglądy, obyczaje, psychologię i obraz świata Sycylijczyków ${ }^{21}$.

Herling, mówiąc o spostrzeżeniach Gustava na temat „struny greckiej” na Sycylii, wyraźnie identyfikuje się z głoszonymi przezeń poglądami. Odnosimy wrażenie, że nie ma żadnej różnicy między pisarzem a jego literackim alter ego. Nawet imię wskazuje na to, iż chodzi o pełne utożsamienie się. Grudziński tworzy epistolarną opowieść, by - poruszając się w jej ramach - dać wyraz swojemu pisarskiemu pragnieniu zgłębienia istoty sicilianità. Początkowo Gustavo przyjmuje względem Rosaria sokratejska postawę naiwnego rozmówcy, obcokrajowca, powtarzajacego utarte sądy na temat wyspy. Celowo ukrywa - zdobyta dzięki licznym lekturom oraz podróży w 1972 roku - wiedzę o Sycylii, by nie uprzedzać swojego rozmówcy. Rosario w jednym $z$ listów komentuje dyletanctwo przyjaciela:

Z jakąś ujmującą dla mnie, Sycylijczyka, zachłannością zarzuciłeś mnie pytaniami. Widać było, że mało o Sycylii wiesz, chociaż Cię ona pasjonuje, i że Twoja podróż sycylijska w roku 1972 była zaledwie wstępem do solidniejszej, dłuższej eksploracji. [Z 107]

Rosario, podsumowując poziom wnikliwości Gustava, stwierdza, że wyspa, jak ja postrzega jego przyjaciel, to „Sycylia powszechnie znana, powierzchowna, na widoku publicznym" (Z 108). Okazuje się jednak, że Sycylijczyk padł ofiara sokratejskiej ironii. Rosario dał się zwieść pozornej niewiedzy i ignorancji Gustava:

Zdziwiło mnie, szczerze mówiąc, że piętnastoletni pobyt we Włoszech nie nauczył Cię sięgania głębiej. Ostatecznie wydawali już swoje przenikliwe książki Sciascia i Brancati, a książę Tomasi di Lampedusa zdażył tuż przed śmiercią pokazać i przybliżyć Sycylię historyczną i zarazem wieczną w swoim arcydziele Il Gattopardo. Poza tym nie wierzę, byś jako pisarz nie znał Pirandella i Vergi, którzy tajemniczą „sycylijskość” usiłowali wytłumaczyć w swoich dramatach i powieściach. [Z 108]

\section{W odpowiedzi Gustavo wyjaśnia Rosariowi przyczyny owej gry:}

Zdradzę Ci, dlaczego to zrobiłem. Chodziło mi o uniknięcie popisu „znajomości przedmiotu”, który tak często występuje u cudzoziemców interesujących się Sycylią. Chciałem Ci narzucić własny obraz turystycznego wciąż (mimo piętnastu lat spędzonych we Włoszech) dyletanta, skazanego na wszystkie stopnie nauki, poczynając od abecadła. [Z 109]

Wprowadzając swojego przyjaciela do wnętrza sycylijskiego świata, Rosario proponuje ujęcie istoty sicilianità, rozważając ją za pośrednictwem trzech wzajemnie się przenikających obsesji:

Trzy są sycylijskie obsesje, które może nie wszystko, ale dużo wyjaśniają. Obsesja śmierci: jedną 
z jej postaci jest wysoka frekwencja samobójstw (a znamiennym wyrazem zewnętrznym sycylijskie łakocie dla dzieci w kształcie czaszek i piszczeli).

Obsesja miłości fizycznej, dowcipnie, choć z gorzkawą prześmiewką, opisana przez Brancatiego (uważa go się, nie bez racji, za sycylijskiego Gogola). I - last but not least- dość skomplikowana obsesja władzy, dla wielu jeden z podstawowych czynników mafii. [Z 108-109]

Klucz do zrozumienia wielu sycylijskich paradoksów zaproponowany przez Rosaria nie jest autorskim pomysłem Herlinga. W samym opowiadaniu padaja wszak nazwiska sycylijskich pisarzy (wymienieni są: Giovanni Verga, Luigi Pirandello, Giuseppe Tomasi di Lampedusa, Vitaliano Brancati i - oczywiście - Leonardo Sciascia), którzy dążyli do tego, by zgłębić fenomen odrębności wyspy. Gustavo, starając się odpowiedzieć na pytanie, dlaczego Sycylia jednocześnie tak go pociąga i niepokoi, stwierdza:

spróbowałem określić źródło mojej fascynacji Sycylią. Jej kultura była skrzyżowaniem wielu kultur: Sciascia wymienia składniki greckie, rzymskie, bizantyjskie, arabskie, hiszpańskie, niemieckie, francuskie. Tomasi di Lampedusa w monologu księcia Saliny skierowanym do wysłannika $z$ Piemontu, wydobywa niezwykły fenomen kultury zamarłej w swojej złożoności. Zamarłej, prawie zmartwiałej i znieruchomiałej, nagiej od momentu, w którym się przed wiekami uformowała. Oto „sycylijskość” w najogólniejszym zarysie. [Z 110]

Nie powinien budzić zdziwienia fakt, że w sycylijskim opowiadaniu Herling powołuje się na słynny monolog księcia Saliny. To wszak jedna z najbardziej inspirujących, najczęściej przytaczanych diagnoz wyspiarskiej mentalności:

Jesteśmy starzy, panie Chevalley, bardzo starzy. Od co najmniej dwudziestu pięciu stuleci dźwigamy na barkach ciężar wspaniałych różnorakich cywilizacji, które wszystkie, zanim przyszły do nas, były już w pełni ukształtowane i udoskonalone, z których żadna nie zakiełkowała dzięki nam, żadnej nie naznaczyliśmy swoją odrębnością [...].

To jest sen, drogi panie Chevalley, Sycylijczycy pragną tylko snu i będą zawsze nienawidzili każdego, kto zechce ich przebudzić, choćby nawet przywoził im najpiękniejsze dary [...]. Wszystkie zjawiska sycylijskie są zjawiskami sennymi, nawet te najbardziej gwałtowne: nasza zmysłowość jest pragnieniem zapomnienia, nasze strzelaniny i porachunki nożownicze sa pragnieniem śmierci; pragnieniem lubieżnego bezruchu, czyli znowu śmierci, jest nasze lenistwo, nasze sorbety ze skorzonery albo z cynamonu; nasz wygląd medytujących jest przejawem nicości, która chce przeniknąc zagadkę nirwany. Stąd bierze się u nas arogancja pewnych osób, tych, które już się na wpół przebudziły, stąd to sławetne opóźnienie o całe stulecie sycylijskich dokonań artystycznych i myślowych; nowości pociagają nas dopiero wtedy, kiedy je uznajemy za obumarłe, jesteśmy niezdolni do powoływania do życia witalnych prądów; stąd to niesłychane zjawisko tworzenia się u nas dzisiaj, współcześnie, mitów, które byłyby godne czci, gdyby były naprawdę antyczne, ale nie są niczym innym jak tylko złowrogą próbą zmienienia życia w przeszłość, która nas pociagga właśnie dlatego, że jest martwa ${ }^{22}$.

Nieco dłuższy fragment tej wypowiedzi tłumaczy Herling-Grudziński w swoim szkicu Il Gattopardo, napisanym w 1959 roku. Tezy księcia Saliny opatruje znamiennym komentarzem:

Nie przeceniać tej filipiki, wzruszyć ramionami pamiętając jej datę? Zapewne w jakimś stopniu tak. Ale przecież w pewien sposób dotyczy ona jednak również dzisiejszej Sycylii, gdzie ,jedynym autentycznym suwerenem jest nadal słońce", gdzie w każdym małym miasteczku ogląda się na rynku czarno ubranych mężczyzn siedzących godzinami bez ruchu pod białymi ścianami domów aż do dnia, w którym 
z nieznanej ręki padnie strzał sycylijskiej lupary i jednego z nich położy trupem, gdzie nikt nie jest w stanie rządzić bez poparcia mafii, gdzie samobójstwa i wypadki obłędu są równie naturalne jak śluby i porody, gdzie czci się śmierć, a słodycze dla dzieci wyrabia się w kształcie czaszek i piszczeli, gdzie śpi się często i długo podczas dnia, gdzie usta ludzkie zdają się zakneblowane, a wie się natychmiast o wszystkim, gdzie za zadraśnięcie czyjegoś honoru płaci się krwią, gdzie strach i omertà czają się za każdym węgłem, gdzie protest społeczny wyraża się induską głodówką à la Danilo Dolci²3.

Aby przeniknąć do wnętrza sycylijskich obsesji, Herling stara się poznać przyczyny i konsekwencje wspominanej przez Rosaria (cytującego Sciascię) antymetafizyczności. Szczególnie interesujące okazują się w takim kontekście rozważania dotyczące problemu religijności Sycylijczyków. Gustavo podejmuje ten temat w związku z oglądaną palermitańską procesją wielkanocną. Kolejny raz głównym literackim przewodnikiem po wyspiarskiej rzeczywistości (i mentalności) jest Sciascia. To bowiem lektura przywoływanego już tu szkicu Feste religiose in Sicilia była swoistym wstępem, przygotowaniem do tego, co Gustavo miał ujrzeć na ulicach sycylijskiego miasta:

Jako pierwsza sycylijska lekcja - a pojechałem przecież „uczyć się” Sycylii - Procesja Wielkanocna w Palermo była lekcja o wielkiej wadze; trudno było lepiej zacząc edukację sycylijska. Ale byłem do obrazu w Vucciria trochę przygotowany. Leonardo Sciascia, autor szkicu o świętach religijnych na Sycylii, pisał w nim, co następuje: „Nie ma na Sycylii miejscowości, w której Męka Chrystusa nie odżywałaby w prawdziwym przedstawieniu, odgrywanym przez żywych na placach i ulicach jako wielki dramat o zdradzie, o zabójstwie i o bólu matki” ${ }^{24}$. Zdaniem pisarza sycylijskiego, doskonałego znawcy swojej ojczystej wyspy, Procesja Wielkanocna na Sycylii przełożona jest na język surowego i ziemskiego realizmu, prawie całkowicie oderwanego od symboliki religijnej. Oto dramat człowieka, zwykłego człowieka, zdradzonego przez swego sasiada, zabitego przez Prawo. A jego matka jest tylko i wyłącznie sycylijską matką bolesną; także jej dramat macierzyńskiego bólu ma wymiar ziemskiej dosłowności i nieustannej aktualności. To ona w Procesji Wielkanocnej na Sycylii jest najważniejsza, najbardziej wzrusza i najgłębiej przejmuje, a nie Chrystus, martwy już w momencie schwytania. To ona, matka, przeżywa dramat ziemski, cielesny, a nie dramat boskiej ofiary i ludzkiego odkupienia; dramat codziennego i dotykalnego bólu życia, zgrozy śmierci i wieczystej żałoby żywych. Męka Pańska jest na Sycylii, w obramowaniu Procesji Wielkanocnej, kontemplacją śmierci wyzutą z jakichkolwiek elementów transcendencji. [Z 114-115]

Gustavo jedzie na Sycylię „zainfekowany” konkretną wiedzą na temat tej wyspy. Można odnieść wrażenie, że widzi to, co przeczytał, albo - lepiej powiedzieć - że komentuje, to, co zobaczył w sposób z góry przewidziany. Opisując palermitańską procesję, nie przekracza interpretacyjnego horyzontu nakreślonego przez Sciascię. Co więcej, ucieka się do cytatów z eseju Sciascii lub parafraz jego najcelniejszych sformułowań $^{25}$. Zdaje się, że Gustavo nie przybył na Sycylię, by - jak deklaruje -

G. He r ling - G r u d zi ń s ki, Il Gattopardo. W: Godzina cieni. Eseje. Warszawa 1997, s. 240-241. Pisma zebrane, t. 8.

24 Zob. też S cia s c i a, Feste religiose in Sicilia, s. 227.

25 Zob. ibidem, s. 227-228: „Niewątpliwie w tych [tj. pasyjnych] przedstawieniach czuje się, że ważniejsza niż sam Chrystus jest postać Matki Bolesnej, która jest zraniona i poruszona. Chrystus, od momentu pojmania, jest już wydany na śmierć. A martwy jest martwy, jak mówią wszystkie przysłownia, które doradzają spokój, pogodzenie się i milczenie. Ale Matka jest żywa: pogrążona w bólu, zakryta czarnym płaszczem żalu, zraniona, cierpiąca w milczeniu; to obraz i symbol wszystkich matek. Prawdziwy dramat jest Jej: ziemski, cielesny. Nie dramat Boskiej ofiary i odkupienia ludzkości, ale bólu istnienia, ciemnego, głęboko zakorzenionego lęku przed śmiercią, zakrytej 
uczyć się jej, ale by potwierdzić zdobytą wcześniej wiedzę. Proces weryfikowania literackiej wizji Sycylii jest w tym przypadku tożsamy z jej konfirmacją:

Stojąc w tłumie na chodniku ulicy w Vucciria, patrząc na mężczyzn zmieniających się w procesji pod ogromnym ciężarem niesionych figur, na pozór symbolicznych, a w rzeczywistości równie realnych jak drzewce noszowe i nagie spocone ramiona tragarzy, słysząc wybuchy płaczu i krzyków, czując od tyłu gorący oddech przemieszany z jękiem, wiedziałem, że Sciascia pisał prawdę, każdym swoim słowem odsłaniał znaczenie religii na Sycylii. Czyli wiedziałem i wi działe m, że nie jest ona religia w takim sensie, jaki posiada na ogół dla wierzących w innych częściach świata. Że dla Sycylijczyków nie jest nawet misterium, lecz powszednim teatrem rzeczywistości; teatrem życia i śmierci. [Z 115]

Gustavo najpierw „wiedział”, a potem „wi d zi ał”, czyli potwierdził. Silne doświadczenie emocjonalne, jakie wywołała w nim procesja wielkanocna w Palermo, było niejako zaprogramowane. Podobne reakcje na widok sycylijskiej procesji opisuje w wydanym w 2004 roku tomie esejów Na Sycylii (In Sicilia) biograf i wielbiciel twórczości Sciascii - Collura:

Trzeba by zobaczyć twarze (pokazał je Rossellini w filmie Podróż do Włoch), kiedy po ulicach ida amatorscy, ale jakże przekonujący aktorzy, którzy odgrywają ową mistyczną tragedię. I trzeba by zobaczyć, jak przy ponurych dźwiękach bębnów w powolnym i falującym pochodzie przypominającym jakiś danse macabre idą zakapturzeni mnisi. I zobaczyć trzeba tych Chrystusów z papier mâché albo drewna, jakże realnych w udręczeniu ciała i kości; i Madonny w welonach, płaczące, ze sztyletami wbitymi w serce: ileż litości, ileż przerażenia, ileż gniewu i ileż chęci zemsty! A wszystko to głównie $z$ jej powodu, cierpiącej Matki, zmuszonej odgrywać swoją straszliwą rolę na zatłoczonych placach, słuchającej w oszołomieniu w szczytowym momencie „święta” rozdzierającego głosu seminarzystów: „Or su versate lacrime / angeli mesti in cielo [...."26.

Także w rozważaniach Collury odciśnięte zostało wyraźne piętno eseju Feste religiose in Sicilia Sciascii: eksponowanie tragedii Matki, której lament i realny, fizyczny ból wzbudzają w tłumie widzów empatyczne reakcje współcierpienia oraz - jednocześnie - pragnienie ukarania winnych. Ponadto Collura, podobnie jak Sciascia (i Grudziński), zwraca uwagę na udosłownienie, realność cierpienia spowodowanego śmiercią ${ }^{27}$.

Z obsesją śmierci łączy się kolejny eksploatowany przez Herlinga (a wcześniej wykorzystywany przez wielu sycylijskich pisarzy) temat - żałoby. Grudziński kwestię tę podejmuje inaczej niż problem religijności (rozważany w eseistycznych par-

i wiecznej żałoby żyjących. I mogłoby się wydawać, że - jakkolwiek pojęta - Pasja wzbudza wśród Sycylijczyków chwilę autentycznego natchnienia religijnego, lecz w rzeczywistości stanowi element kon templacji śmierci, która może być wyrazem świata zupełnie wyzbytego transcendencji. Jeśli da się mówić o religii bez transcendencji, wówczas religijna jest ta k o n te m pla cja ś m i e rc i, która w Pasji znajduje swoją najbardziej przejmującą reprezentację".

M. Collu ra, Na Sycylii. Przekł., posł. J. U gn i ew s ka. Warszawa 2013, s. 51.

27 Herling-Grudziński w rozmowie z Boleckim (Rozmowa XV, s. 272) - dając do zrozumienia, że w trakcie jednej z podróży na Sycylię uczestniczył w typowej dla tej kultury procesji - raz jeszcze stwierdza, powołując się na ustalenia Sciascii: „nie widziałem nigdy takiej procesji Wielkanocnej jak u nich. Nie było w niej cienia transcendencji czy symboliki. To było po prostu konkretne zdarzenie - dokładnie tak jak opisał to Sciascia. Dla Sycylijczyków misterium Wielkiej Nocy to po prostu historia człowieka, który został zdradzony przez swojego sąsiada, skazany na śmierć przez niesprawiedliwe prawo, nad którego trupem płacze jego matka - nic więcej. Czyli to jest historia, która zdarza się w każdej wsi na Sycylii przeniesiona w wymiar religijny, ale rozumiana najzupełniej dosłownie". 
tiach listów), prowadzący do - powtarzanego za Sciascią - wniosku o kontemplacji śmierci. W Zielonej Kopule wątek żałoby wpleciony jest w relacjonowaną historię i powraca kilkakrotnie. Gustavo wspomina w liście do Rosaria o reakcji, jaka wywołała wiadomość o niecodziennej dacie ślubu sycylijskiego przyjaciela:

Zaraz po egzaminach zaskoczyłeś i mnie, i Twoich kolegów w instytucie oznajmieniem, że żenisz się w Zaduszki w Pietrasanta, w miejscowości rodzinnej Twojej przyszłej żony. W Zaduszki, właśnie w Zaduszki? Nie patrząc mi w oczy, powiedziałeś cicho: „Od samobójstwa mojego starszego brata w naszym domu w Paternò obowiąuje żałoba, nawet radosny dzień musi być przesłonięty czerniạ”. [Z 112]

Ta nie kończąca się żałoba, która bardzo prozaicznie łączy się z miłością fizyczną, scharakteryzowana została również za pośrednictwem historii pewnej sycylijskiej wdowy. W taki sposób przedstawiono nierozerwalny splot dwóch obsesji Sycylijczyków - śmierci i miłości fizycznej. Gustavo, relacjonując swój pobyt w Erice, wspomina, że mieszkał tam w wynajętym u wdowy pokoju:

Pokój był czysty i przyzwoicie umeblowany, z małym tarasem i ślicznym widokiem, obwieszony na wszystkich ścianach portretami mężczyzny o surowym spojrzeniu, w sztywnym, czarnym surducie. Samotna i bezdzietna wdowa po nim (od pięciu lat) imieniem Rosalia była czarno odzianym posagiem żałoby. Widywałem ją rzadko, ale jej ciagła obecność wypełniała mieszkanie sensualną falą. Co noc przychodził do niej kochanek, przed świtem wymykał się furtką uliczną jak cień wyrwany z muru. Może przesadzam, może posuwam się za daleko, ale to tam, w Erice, słuchając odgłosów w pokoju Rosalii, również obwieszonego portretami zmarłego męża, dotknąłem „typowego zjawiska sycylijskiego” (zdaniem znawców), uścisku miłości i śmierci, Erosa i Thanatosa, tak naturalnego, jakby nie wolno było rozłączyć tych dwóch elementów pod groźbą klątwy. [Z 116-117]

Po raz trzeci temat żałoby powraca w związku z głównym wątkiem narracyjnym ${ }^{28}$ :

5 maja odprowadziłeś mnie do pociagu w Katanii. Ledwie odsapnąłem w Neapolu po sycylijskim miesiącu, 10 maja 1972 przeczytałem w gazecie korespondencję z Pietrasanta Mord sycylijski. Dwa dni z rzędu usiłowałem bezskutecznie dotelefonować się do Was w Pietrasanta. Trzeciego dnia wysłałem depeszę do Twoich rodziców w Paternò. Oddzwoniłeś stamtąd, ale po to właściwie, by zapowiedzieć z powodu żałoby przerwę w naszych kontaktach. „Przerwa”, wypełniana od czasu do czasu lakonicznymi kartkami i krótkimi telefonami, trwała ćwierć wieku. Nie do wiary, chociaż wiedziałem już coś o sycylijskiej żałobie. Zatrzasnęły się na dwadzieścia pięć lat drzwi Waszego domu w Paternò. Pirandello nauczył mnie dwóch rzeczy: że życie jest pasmem absurdów; i że istnieje absolutna sycylijska nieobliczalność, nieprzewidywalność; istnieją na Sycylii zachowania, których sprężyny niepojęte są dla samych protagonistów. Dopiero w marcu 1997 wydobyliście Wasz dom ze zwojów czerni. [Z 126]

Don Cesare, teść Rosaria, okazuje się szefem „wiejskiej mafii” sycylijskiej, jego żona, Donna Emilia, pozostaje w jego cieniu, najprawdopodobniej jednak łaczy ja silna więź z córką Dorą. Można odnieść wrażenie, że Herling skupia się początkowo nie tyle na skomplikowanych relacjach rodzinnych, ile na przedstawieniu struktury władzy w Pietrasanta: „Układ Pietrasanta zdawał się służyć podkreślaniu dominacji Pana i Władcy pod Zieloną Kopułą" (Z 122). Dopiero przybliżenie okoliczności i niewyjaśnionych powodów śmierci matki - w ustach zmarłej odnaleziono kamień, „mafijny dowód zdradzonej tajemnicy lub policyjnego donosu, ale bez precedensu

28 Trudno tu mówić o właściwej narracji. Problem hybrydyczności Zielonej Kopuły zdaje się podejmować Herling zawierając w podtytule opowiadania wskazówkę genologiczną - „opowieść epistolarna”, oraz pisząc o konieczności „narracyjnego wtrącenia” (Z 126) we fragmencie, w którym odchodzi od formy listu (Z 126-130). 
wobec kobiet” (Z 127) - rzuca trochę światła na stosunki panujące w rodzinie Dory. Wszelkich szczegółów dostarcza Gustavowi aptekarz mieszkający po sąsiedzku z rodziną Don Cesarego. To on sugeruje, że nienawiść Dory odczuwana w stosunku do własnego ojca związana była z przemocą seksualną, której kobieta stała się ofiarą. Śmierć matki okazuje się dla niej ciosem nie do udźwignięcia i skutkuje wieloletnią, sycylijską $z$ ducha, żałobą:

Ta kobieta odżywa dopiero po śmierci ojca, którego nienawidziła, ale też po długim okresie żałoby po śmierci matki. Trudno uwierzyć, że na Sycylii żałoba może trwać tak długo - w tym wypadku dwadzieścia pięć lat - i przez cały ten czas wciąga żywych w krąg umarłych ${ }^{29}$.

Symbolicznym kresem cierpienia Dory staje się śmierć ojca, który ginie w swojej posiadłości w wyniku wybuchu. Za zamachem - jak sugeruje Gustavo - stoi prężnie działająca, nowoczesna mafia pragnąca przejąć kontrolę nad rządzonym przez Don Cesarego latyfundium:

Don Cesare był Capomafia? Był, ale na średnim poziomie w trójkącie Paternò - Pietrasanta - Piazza Amerina. Ówczesna mafia rurale, mafia wiejska, nie może się nawet równać z obecną, potężną i rozgałęzioną na cały świat (przede wszystkim Amerykę) mafią o miliardowych obrotach w dziedzinie budownictwa, inwestycji przemysłowych, narkotyków, handlu bronią, „prania brudnych pieniędzy” w zaprzyjaźnionych, a często pokątnie posiadanych, bankach. Mafia rurale, pierwotna komórka gigantycznego organizmu, dawała jej przywódcom coś w rodzaju rosyjskiego „rejestru dusz” w ubiegłym stuleciu, przed uwłaszczeniem chłopów przez carat. Chłopi w mafia rurale byli nominalnie wolni, ale zależeli całkowicie od mafijnego nadzoru, czyli od Capomafia w asyście grupy zaufanych. To właśnie był drugi powód uwieńczenia kopuła zamku czy pałacu Don Cesare. Kopuła, jako szczyt organizacji hierarchicznej, stawiała podówczas pierwsze kroki. [Z 125-126]

Podobne rozważania na temat mafii snuje w przedmowie do książki Fabrizia Calviego Sciascia i podkreśla:

zrodzona $\mathrm{z}$ feudalizmu i przejmująca jego formy (szef mafii zastępuje feudała, któremu przysługuje przywilej „władzy udzielnej i lenniczej”, to znaczy, że nad mieszkańcami miast i wsi sprawuje prawo życia i śmierci, ma też suwerenne wręcz prawo podnoszenia podatków) mafia powinna była dokonać pewnego postępu, porównywalnego z przejściem ze społeczeństwa feudalnego do społeczeństwa burżuazyjnego $[\ldots]^{30}$.

Punktem docelowym mafijnej historii opowiedzianej przez Herlinga w Zielonej Kopule jest refleksja nad trzecia $z$ sycylijskich obsesji - obsesją władzy. Obaj pisarze: tak polski, jak i sycylijski, byli przekonani, że jej przejawem jest, mityczna już, sycylijska organizacja mafijna. Ukazując w literackim skrócie jej mechanizm, Grudziński pragnie stanać niejako obok podziwianego Sciascii, który do perfekcji dopracował technikę opowiadania (i niedopowiadania) sycylijskich historii z mafijnym tłem.

Jednak utworem Sciascii, który najbardziej zaimponował Grudzińskiemu i który - jak sądzę - wywarł największy wpływ na jego warsztat prozatorski, była opublikowana w 1964 roku, wspomniana już tu, książka Morte dell'Inquisitore. Herling jeszcze w tym samym roku na łamach paryskiej „Kultury” (1964, nr 5) przygotował

29 Herling-Grudziński, Bolecki, Rozmowa XV, s. 268.

30 L. S cia s c i a, przedmowa w: F. C alvi, Życie codzienne mafii od roku 1950 do naszych dni. Przeł.

J. W a c zków. Warszawa 1993, s. 10. 
jej omówienie w cyklu zatytułowanym $Z$ zeszytu lektury. Zawarty tam szkic Fra Diego przedstawia historię procesu inkwizycyjnego głównego bohatera powieści Sciascii, sycylijskiego zakonnika (augustianina) - Fra Diega La Matina. Wyjątkowość tej postaci Herling sygnalizuje już na wstępie:

W dziejach Inkwizycji znane są tylko dwa wypadki zamordowania Inkwizytora. W roku 1485 Pedro Arbues został nocą zwabiony do zasadzki i zamordowany przez aragońskich conversos (nawróconych Żydów). W roku 1657 Juan Lopez de Cisneros zginął w podziemnym więzieniu Inkwizycji w Palermo z ręki Fra Diego La Matina, braciszka z zakonu augustianów. Skape materiały kronikarskie zdają się wskazywać, że podczas przesłuchania Fra Diego rozerwał kajdany i strzępem łańcucha ugodził Inkwizytora śmiertelnie w głowę. Pisarz sycylijski Leonardo Sciascia zrekonstruował teraz z tej historii, co się dało, w niezwykłej książeczce Morte dell'Inquisitore ${ }^{31}$.

Grudzińskiemu nie imponuje heroiczny mord, ale ludzkie pragnienie ziemskiego życia, któremu wyraz daje Fra Diego tuż przed śmiercią:

Ponieważ droga do stosu była długa, przeniesiono go z krzesła na wóz zaprzężony w dwa woły. „Na widok stosu (notuje kronikarz) nie zmienił się, nie zmieszał się, nie zdradził oznak lęku lub strachu”. Dwaj asystujący mu księża nie ustawali w próbach wyduszenia zeń dowodów „,̇alu za grzechy”, w końcu jednak musieli dać za wygraną. Dwukrotnie sfingowano podpalenie stosu, sądząc, że blask ognia złamie jego rogatą duszę. Nagle przywołał gestem jednego z księży. Wyjęto mu knebel, z umęczonych ust padły słowa: „Zmienię zdanie i poddam się Kościołowi katolickiemu, jeśli mi życie cielesne podarujecie”. Na co ksiądz nazwiskiem Giuseppe Cicala: „Wyrok jest nienaruszalny”. Na co Fra Diego: „Czemuż tedy powiedział prorok: Nolo mortem peccatoris, set ut magis convertatur, et vivat" ${ }^{32}$. Na co Don Giuseppe: „Życie duszy miał na myśli Prorok, nie zaś życie ciała”. Na co Fra Diego: „A więc Bóg jest niesprawiedliwy"33.

Zaproponowana przez Sciascię konkluzja zdaje się przekonywać Herlinga, który słowami sycylijskiego pisarza zamyka szkic Fra Diego:

W przeszło pół wieku później Fra Diego znalazł swego hagiografa w osobie takiegoż jak on zakonnika, Fra Romualda $z$ Caltanisetty [!]. Fra Romualdo zapewniał, że braciszek z Ragalmuto był „świętym męczennikiem". Spalono go na stosie w Palermo 6 kwietnia 1724 roku (wraz z oddaną mu Suor Geltrudą) jako „molinistę” i krytyka wyroków Świętej Inkwizycji. „Święty męczennik - kończy swoją książeczkę Sciascia. - Lecz ja utrwaliłem te dzieje, by wydano inny sąd o naszym rodaku: że był człowiekiem, że wysoko stawiał godność ludzką"34.

Po 18 latach, 20 II 1982, Grudziński w swoim Dzienniku pisanym noca zamieścił dłuższą notatkę dotyczącą Morte dell'Inquisitore. Powtarza tam dawniejsze sądy, niektóre zdania ze szkicu Fra Diego przytacza wręcz in extenso. Podkreśla, że dystans czasowy, dzielący go od pierwszego spotkania $z$ książką Sciascii, nie zmienił jego stosunku do augustianina:

Wczoraj w nocy, szukając na półkach czegoś do czytania, czegoś możliwie oderwanego od chwili bieżącej, trafiłem na zakurzoną, rozprutą od kilku lektur, pokreśloną i upstrzona notatkami Śmierć Inkwizytora. Sto stronic zaledwie, połknąłem je w dwie godziny. $Z$ uczuciem - jak to określić? - uchy-

31 G. Herling-Grudzińs ki, Z zeszytu lektury. Fra Diego. W: Godzina cieni, s. 243.

32 Tłumaczenie polskie: „Nie chcę śmierci grzesznika, lecz raczej by się nawrócił i żył” (Ez 33, 11).

33 Herling-Gru dziń s ki, Zzeszytu lektury, s. 247. Zob. też L. S c i a s c i a, Morte dell'Inquisitore. Milano 2013, s. 79-80.

34 Herling-Grudzińs ki, Z zeszytu lektury, s. 248. Zob. też S c i a s cia, Morte dell'Inquisitore, s. 99-100. 
lenia wieka trumny i zobaczenia w niej twarzy umarłego nie zmienionej po latach, niezmiennie wyrazistej, lecz o rysach zaostrzonych, piękniejszych, żywszych, jak gdyby z otwartych ust dochodził szept: „Umarłem, by nie umrzeć”. A więc tak bliski pozostał mi braciszek z sycylijskiego Ragalmuto! Tak bardzo bliski, że czas wydobył na jego martwą i zbielałą twarz rumieniec życia! ${ }^{35}$

Istotny okazuje się komentarz kończący wpis. Herling dodaje go po kolejnej lekturze Morte dell'Inquisitore. Raz jeszcze przytacza krótką rozmowę, którą z Fra Diegiem prowadził ksiądz Giuseppe Cicala, na moment przed spaleniem zakonnika na stosie, tłumaczacc, że to przede wszystkim ostatnie słowa augustianina sprawiły, iż ocenił go wysoko jako człowieka:

Właśnie dzięki tej nagłej (i daremnej) zmianie Fra Diego jest mi tak bliski. Bo moje zapatrzenie w niego nie jest zapatrzeniem w oleodruk męczennika bez skazy, lecz miłością do człowieka $\mathrm{z}$ krwi i kości, który broniąc do upadłego swej ludzkiej godności, potyka się po ludzku i ugina na słabnących nogach, by natychmiast wyprostować się, nie dotknąwszy kolanami ziemi. Umiera, by nie umrzeć36.

Można rzec, że Sciascia osiagną̧ swój cel. Grudziński jako wnikliwy i wierny czytelnik Morte dell'Inquisitore wydaje inny sąd o Fra Diegu. Zakonnik - przekonuje Herling - nie upada jako człowiek, nie traci człowieczeństwa, wręcz przeciwnie, walczy o nie. Znamienne jest to, że Grudziński wybiera i stawia jako wzór książkę tak silnie dokumentarna. Sciascia, opierając się na materiale źródłowym, stworzył jednak coś więcej niż historyczną, noszącą znamiona naukowości, rozprawę. Jeśli weźmiemy pod uwagę poziom refleksji sycylijskiego pisarza, widzimy w Morte dell'Inquisitore wybitny esej - próbę udzielenia odpowiedzi na pytanie o zwykła, ludzką wolę życia.

Herling, budując wiele ze swoich opowiadań na fundamentach historii zaczerpniętych z kronik włoskich, bazując na - oczywiście, literacko przetworzonych tekstach źródłowych, czyni swój pisarski warsztat podobnym do pisarskiego warsztatu autora Morte dell'Inquisitore. Nie powinien zatem dziwić fakt, że Grudzińskiemu przypadła do gustu również inna oparta na faktach książeczka Sciascii, zatytułowana Zniknięcie Majorany. Wydaną w 1975 roku niewielkich rozmiarów powieść Herling przywołuje w swoim dzienniku 6 II 1976, rozważając przyczyny zniknięcia sycylijskiego fizyka oraz snując hipotezy na temat jego dalszych losów. Ettore Majorana zaginą 25 III 1938. Grudziński, powołując się na ustalenia Sciascii, w specyficznej - by tak rzec - nadświadomości naukowca, przerażonego przewidywanymi zgubnymi rezultatami prowadzonych badań, szuka powodów jego ucieczki od świata:

La scomparsa di Majorana, sugestywna książeczka Leonardo Sciascia, stanowi rekapitulację tego, co wiadomo o „tajemniczym dramacie duszy i nerwów” fizyka włoskiego. Sciascia opowiada się zdecydowanie przeciw hipotezie samobójstwa, jest za zniknięciem, i to dokładnie uplanowanym w każdym detalu przez umysł nawykły do ścisłości. Ale nie znika się bez głębszego powodu, w końcu i trzydziestodwuletni uczony ma prawo jawnie przenieść się w stan spoczynku. Powodem była wizja, jaką „prekursorski” i „niemal profetyczny” Majorana ujrzał już w roku 1938: wizja grzyba atomowego na horyzoncie fizyki nuklearnej. Majorana chciał swoim zniknięciem zarysować „mit odepchnięcia nauki”, potwora szykującego się do owładnięcia uczniem czarnoksiężnika. [D 187-188] 
Herling, posługując się sformułowaniem „uczeń czarnoksiężnika”, odnosi się najprawdopodobniej do tytułu ballady Johanna Wolfganga Goethego. Napisany w 1797 roku Uczeń czarnoksięski (Der Zauberlehrling) to historia młodego magika, który zbyt szybko uwierzył w swoją moc i, pod nieobecność nauczyciela, zaczął eksperymentować $\mathrm{z}$ czarami:

\author{
Wreszcie czarnoksiężnik stary \\ z domu wyniósł się na dłużej! \\ Teraz ja rozpocznę czary, \\ mnie demony będą służyć! \\ Uważniem go słuchał, \\ gest, zaklęcie znam. \\ Więc $z$ pomocą ducha \\ zrobię dziwy $\operatorname{sam}^{37}$.
}

Kiedy uświadamia sobie, że nie jest w stanie opanować wprawionych w ruch przedmiotów, wzywa na pomoc siły niebieskie i starego nauczyciela. Majorana uniknął pułapki związanej z zafascynowaniem potęgą swego odkrycia. Wręcz przeciwnie, odczuwał lęk, ludzki lęk przed masową śmiercią, dla której wrota mogą otworzyć „wzniosłe” zdobycze uprawianej przez niego nauki. Nie podpisał mitycznego, faustowskiego paktu z Mefistofelesem:

Jeżeli zmarli, mówi Pirandello, są „emerytami pamięci” ${ }^{38}$, zaginieni są jej płatnymi pracobiorcami: opłacanymi trwalszą i dłuższą daniną pamięci. W każdym przypadku. A zwłaszcza w takim jak przypadek Ettore Majorany, w którego mitycznym zniknięciu młodość, cudowny umysł, nauka nabrały mitycznych znaczeń. Sądzimy, że Majorana brał to pod uwagę, chociaż z absolutnym i całkowitym pragnieniem, aby być „człowiekiem samotnym” lub „nie być wcale”; słowem, w swoim zniknięciu przeczuwał, miał świadomość mitu: mitu odrzucenia nauki ${ }^{39}$.

Także Herling ucieka się do pirandellowskiego tropu interpretacyjnego, komentując dramat Majorany. To jednak odniesienie negatywne: „Nie jest, $z$ cała pewnością nie jest, kluczem do jego zniknięcia Pirandellowski Mateusz Pascal” (D 188). Ale okazuje się, że i w tym stwierdzeniu Grudziński nie wydaje się odkrywczy. To wszak Sciascia, doszukując się Pirandellowskich korzeni sycylijskiej osobowości fizyka, jednoznacznie odrzuca kusząca paralelę: Ettore Majorana - Mattia Pascal. Należy podkreślić, iż rozumiana po pirandellowsku samotność Majorany ${ }^{40}$ wiąże Sciascia $\mathrm{z}$ bohaterem innej, ostatniej powieści pisarza $\mathrm{z}$ Agrigento, noszącej tytuł Jeden, nikt $i$ sto tysięcy (Uno, nessuno e centomila):

Przygotowując sobie ,jakąś” śmierć czy śmierć w ogóle, przygotowując się do sytuacji, w której zapomnieć, zapomnieć o sobie i być zapomnianym (co jest prawdziwą śmiercią, ale może być tylko

J. W. G o eth e, Uczeń czarnoksięski. W zb.: Niemiecka ballada romantyczna. Oprac., przekł. Z. Ci e c h a n ow sk a. Wrocław 1963, s. 111 (utwór Goethego przeł. J. G a m s k a- - e m pi ck a). BN II 142.

38 Sciascia odwołuje się do tytułu noweli L. Pir a n d ella I pensionati della memoria (Emeryci pamięci), pochodzącej ze zbioru Donna Mimma, pierwszy raz opublikowanej w styczniu 1914 w piśmie „Aprutium”, później zaś w Novelle per un anno (A cura di M. Costanzo. Introduzione G. M a c chi a. T. 2. Milano 1996, cz. 1, s. 735-739; cz. 2, s. 1299).

39 L. Scia s cia, Zniknięcie Majorany. Przeł. K. F e ke c z. Warszawa 1985, s. 55-56.

40 Zob. ibidem, s. 41: „[Majorana] będzie robił wszystko, aby żyć - na sposób pirandellowski - jak "człowiek samotny". 
śmiercią urzędową, jeżeli z powodu przenikliwości czy powołania nie chce się wracać, nie chce się splatać swojego życia z życiem innych, patrzeć na ich życie, na ich uczucia oczami entomologa; przenikliwości czy powołania, których zupełnie zabrakło Mattii Pascalowi, a miał je natomiast w dwadzieścia lat później Vitangelo Moscarda - a przypominamy te dwie pirandellowskie postacie również dlatego, że dziennikarze i telewizja dopatrywały się podobieństwa Ettore Majorany z Mattią Pascalem, tymczasem dążenia Majorany były raczej zbieżne $z$ dążeniami bohatera Jeden, nikt, sto tysięcy), sądzimy więc, że Majorana przygotowując swoje zniknięcie, organizując je, obliczając, miał przebłysk - w sprzeczności, w przeciwieństwie, w kontrapunkcie - świadomości, że dane jego krótkiego życia połączone $z$ tajemnica jego zniknięcia, mogłyby stworzyć mit ${ }^{41}$.

Herling podsumowuje swój wywód, cały czas pozostając blisko rozważań snutych przez Sciascię:

Legenda o „dziwnym” uczonym współczesnym, „mit odepchnięcia nauki” przez naukowca pozbawionego „zdrowego rozsądku”? Cokolwiek powiemy, półdokumentarna powiastka filozoficzna pisarza sycylijskiego zawiera coś ożywczego, krzepiącego. Dla mnie jest powiastką o ucieczce od diabelskich podszeptów o „wszechmocy” człowieka. [D 188-189]

Majorana, w oczach Sciascii i Herlinga, pozostaje, jak Fra Diego, przede wszystkim człowiekiem.

Pisarstwo Sciascii potraktował Herling jako swoista lekcje na temat Sycylii. Zresztą należy podkreślić, że Sciascia nie jest ani pierwszym, ani jedynym spośród twórców, którzy stali się przewodnikami Grudzińskiego w literackiej (ale także rzeczywistej) wędrówce w głąb niezwykłej włoskiej wyspy. Wszakże nie sama Sycylia, z jej bogactwem, paradoksami i obsesjami wzbudziła zainteresowanie i podziw Herlinga, śledzącego literackie dokonania Sciascii. Uwiodła go także refleksja filozoficzna, która przenika te z pozoru wyłącznie kryminalne lub wyłącznie dokumentarne dzieła, skłaniając do tego, by uważniej pochylić się nad twórczością autora Todo modo. Sądzę, że gdyby Grudziński miał stworzyć własną listę najistotniejszych XX-wiecznych pisarzy europejskich, umieściłby na niej Leonarda Sciascię.

\author{
Abstract \\ MAGDALENA ŚNIEDZIEWSKA Institute of Literary Research of the Polish Academy \\ of Sciences, Warsaw
}

\title{
BEING LIKE LEONARDO SCIASCIA GUSTAW HERLING-GRUDZIŃSKI AND SICILIAN OBSESSIONS
}

The article is a detailed analysis of Leonardo Sciascia's creativity reception in Gustaw Herling-Grudziński's works. Herling, fascinated by the Sicilian, attempts not only to approach to the literary genetic and stylistic problems of Sciascia's novels, but also to the themes discussed in them and the ideological stance they adopt. Sciascia, who in his creativity often based on source materials, is exceptionally close to Grudziński, an indefatigable reader of Italian chronicles. Grudziński not accidentally highly evaluated Sciascia's book Morte dell'Inquisitore based on facts. Such interest tells much about his own creativity. The author of the paper aims to argue that Grudziński intentionally displays such Sciascia's individual traits which he might recognize as characteristic also of his own and views the Sicilian writer's output as a unique lesson about Sicilia with which he is enchanted. 